INTERNATIONAL JOURN AL OF RESEARCHES IN BIOSCIENCES, AGRICULTURE AND TECHNOLOGY (c) VISHWASHANTI MULTIPURPOSE SOCIETY (Global Peace Multipurpose Socie ty) R. No. MH-659/13(N) www.vmsindia.org

\title{
APPLICATIONS OF PROTEIN SERICIN FROM THE SILKGLAND OF SILKWORM: A REVIEW
}

\author{
S.V. Ghonmode \\ Department of Zoology, S.S.E.S.Amt's Science College, \\ Congress Nagar, Nagpur-440012 \\ sharyu.ghonmode@gmail.com
}

\begin{abstract}
:
Silk consists of two types of proteins, silk fibroin and Sericin. Sericin possess nearly about 20-30\% of total cocoon weight. It has sevral uses in pharmaceuticals and cosmetics such as, wound healing, bioadhesive moisturizing, antiwrinkle and antiaging.
\end{abstract}

Keywords: Silk, Silk prote ins, Sericin.

\section{Introduction:}

Sericulture in India-

Silk is a natural protein fiber. The protein fiber of silk is composed mainly of fib roin and is produced by certain insect larvae to form cocoons. The luster and shimmering appearance of silk is due to the triangular prism-like structure of the silk fiber, which allows silk cloth to refract incoming light at different angles, and so producing different colors. Silk is produced by several insects unde rgoing complete metamorphosis, but for textile manufacturing usually the silk of moth caterpillars has been used. Silk production is also observed in many Hyme nop te rans.

Sericulture, in India, is a cottage industry. The post rearing operations are very cost effective and silkworm rearing is still only considered as a side activity to the main farm activity. Waste from the silk can be classified in three different types i.e., waste from the cocoon, rearing waste, and thread waste. Silk fibroin is the protein that forms the filament of silkworm. Silk wastes can be used as coarse yarn and spun silk, which can be incorporated in natural rubber to achieve the physicochemical properties (Iizuka E, Silk physicochemical properties, the polymeric materials encyclopedia, 1996, Cook J G, Natural fibres of animal origin (Silk) ; Handbook of textile fibres 1964).It is also possible to utilize the silk waste by extracting fibroin and Sericin from silk polymer, which helps to make sericulture a viable agro industry.

Structure of Silk-

. Sericin is a second type of silk protein, and consists of $20-30 \%$ of total

cocoon weight. The ir function is to envelop the fibroin. The fibres become hard and tough due to the presence of sericin and become soft and lustrous after its removal.

Forms of Silk Sericin-

Sericin can be classified into three fractions depending on their solubility as Sericin A, Sericin B, and Sericin C. The outermost laye $r$ is Sericin and insoluble in hot water. It contains about $17.2 \%$ of nitrogen and amino acids. The middle layer is Sericin B and yields amino acid on acid hydrolysis. The innermost layer is Sericin C, which is adjacent to fibroin and is insoluble in hot water and can be removed from fibroin by treatment with hot dilute acid or alkali. Sericin has been divided into various species based on relative solubilities. Various fractions of Sericin are also designated by other researchers depending on their dissolution behavior as Sericin A and B, or Sericin I, II, III, and IV, or S1, S2, S3, S4, and S5, and as $\alpha, \beta$, and $\gamma$ modification (Komatsu K, Silk its formation, structure, character, and utilization; the polymeric materials encyclopedia, (1996); Voegeli R, Meier J \& Blust R, Sericin silk protein: unique structure and properties, (1993). The repeated moisture absorption makes molecular aggregation structure denser and forms more crystalline structure, which is having reduced solubility.

The $\gamma$-ray study shows that the re are three layers in Sericin structure. The outer layer contained some fibre direction filaments, middle laye $r$ has cross fibre direction filaments, and the inner layer bears longitudinal filaments (Wang T, et.al, $\gamma$-Ray study on the Sericin structure of cocoon silk, Fangzhi Xuebao, (1985). The structure of Sericin also depends on the casting temperature. Lower the casting temperature more the Sericin molecules assume $\beta$-sheet structure rather than random coil(Tsukada $\mathrm{M}, \mathrm{J}$ Polym Sci: Polym Lett Ed, (1980) ; Ayub Z H, Arai M \& Hirabayashi K, Biosci Biotechnol Biochem, (1993). Applications of Silk Sericin-

Due to the proteinous nature of Silk Sericin it is susceptible to the action of proteolytic enzymes present in body and hence it is digestible. Which makes it a biocompatible and 
biodegradable material. Because of some additional properties like, gelling ability, moisture retention capacity, and skin adhesion it has wide applications in medical, pharmaceutical, and cosmetics.

Medical and Pharmaceutical Applications-

Sericin is soluble in hot water and after some time proceeds it converts into gel. Jun et al., Studies on physical properties of Sericin gel, Canye Kexe, (1997) have found that conversion of a-random coil to $\beta$-sheet structure gives gel. $1 \%$ aqueous Sericin solution produces gel at $\mathrm{pH}$ 6.7 at room temperature and gelation speed increases as the concentration of Sericin increases (Hirabayashi K, et.al)., Gelation of silk Sericin ;Nippon Sanshigaku, Zasshi, (1989) ; Zhu, L J, Hizahayashi K \& Aari M, Gelation of Sericin and its structure and properties,1991). The aqueous Sericin solution containing 1.5 and $2 \% \mathrm{w} / \mathrm{w}$ of Sericin obtained by autoclaving at $105^{\circ} \mathrm{C}$ for $30 \mathrm{~min}$. does not show good gelling. In the presence of pluronic Sericin gel it shows concentration dependence (Padamwar M N \& Pawar A P, Preparation and evaluation of Se ricin gels containing choline salicylate, (2003); Kewon et al. Effe ct of poloxamer on the gelation of silk Sericin, Macromol (2000) have shown the effect of concentration of pluronic and te mperature on the gel property of Sericin. The gelling of Sericin is accelerated with increase in temperature and with increase in poloxamer concentration, whe reas the solgel transition of Sericin becomes irreversible. Blends of polyvinyl alcohol and Sericin are cross linked to give hydrogels. Hydrogels with good mechanical strength and water resistance are produced by casting aqueous solution containing Sericin and dimethyl urea on a glass plate and heating at 80 and $120^{\circ} \mathrm{C}$ for 1 and $3 \mathrm{~h}$, respectively (Nakamura K \& Koga Y, Sericin containing polymer hydrogels and their manufacturer, 2001).

Fibroin and Se ricin, when sulphonated show antithrombotic effect (Yasushi T, Antithrombotic agent and its production method, 1997). A concentration of $0.011 \mathrm{mg} / \mathrm{mL}$ in blood exhibits anticoagulant, fibrinolytic, and antiaggregation activity towards thrombocytes at $0.5 \mathrm{mg} / \mathrm{mL}$ ( Khudaibe rdiev M. A., Synthesis of copolymer processing an anticoagulant action, 1997).

Sericin has been found to possess wound healing property and can be used as wound healing covering material in the form of film (Wu C., et.al.,Wound protection film and its preparation method, (1996). Sericin also has adhesive property due to its chemical composition. It has affinity to keratin (Voegeli
R., Meier J. \& Blust R., Sericin silk protein: unique structure and properties, (1993). Silk threads obtained from mulberry silkworm can be used for making surgical sutures (Gapurova G. N., Che mical and physicochemical properties of surgical sutures (1983). Silk Sericin membranes are good bandage materials and the film has adequate flexibility and tensile strength. Due to its good biocompatibility and infection resistant nature, it is a novel wound coagulant material. Additionally, its flexibility and water absorption properties promote smooth cure for defects in the skin and do not cause any peeling of the skin under regeneration when detached from the skin (Tsubouchi K, Wound covering material containing silk fibroin and silk Sericin as the main components and process for producing the same, 1998).

Kurioka A, Application of silk proteins to new biomaterial (1998) has explained silk Sericin as a biomaterial. The silk Sericin has the potential to find application in the development of contact lenses. Food with Sericin relives constipation, suppresses development of bowel cancer and accelerates the absorption of minerals. In rats, consumption of Sericin elevates the apparent absorption of zinc, iron, magnesium, and calcium by $41,41,21$, and 17 $\%$, respectively (Sasaki M, Yamada \& Kato N, Composition of silk protein, Sericin elevates intestinal absorption of $\mathrm{Zn}, \mathrm{Fe}, \mathrm{Mg}$, and $\mathrm{Ca}$ in rats, 2000) .A dietary supplementation of $4 \%$ of Sericin suppresses induced constipation in rats because of its low digestibility along with water holding capacity (Sasaki M, Yamada H. \& Kato N., A resistant protein Sericin improves atropine induced constipation in rats, 2000). Sericin, when given orally, causes a dose dependent decrease in the development of colonic aberrant crypt foci. The incidence and the number of colon tumours are suppressed by consumption of Se ricin. Sericin has antitumor activity (Sasaki M., et.al., Silk protein Sericin suppresses colon carcinogenesis, 2000; Kato N. \& Sasaki M., New physiological function of Sericin and its application for cosmetic and food 2000; Kato N, Tomotake H. \& Sasaki M., Nutritional function of resistant protein 1997).

Oxygen permeable membranes are made up of fibroin and Sericin with 10-16\% water and are used for contact lenses, and as artificial skin (Minora N. \& Tsukada M., Oxygen permeable me mbranes, 1990, Heisei, P. (1991).

Cosmetic Applications-

In addition to above mentioned medical and pharmaceutical uses of Sericin, it has been used 
as component of cosmetics. Sericin alone or in combination with silk fibroin has been used in skin, hair, and nail cosmetics. Sericin when used in the form of lotion, cream and ointment shows increased skin elas ticity, antiwrinkle, and antiaging effects (Voegeli R., Meier J. \& Blust R., Sericin silk protein: unique structure and properties, 1993; Yamada H., et.al., Collagen formation promoters containing Sericin or its hydrolyzates and antiaging cosmetics, 1998; Ogawa, A. \& Yamada H., Antiaging cosmetic containing Sericin or hydrolysates and saccharomyces extracts, 1999, Henne W. \& Hoppe U., Light and screening composition, 1985,1986).

Padamwar et al. Evaluation of moisturizing efficiency of silk protein II: silk Sericin, (2002) have shown the moisturizing property of the Sericin gel, Sericin gels increase the hydroxyproline content in stratum corneum and decrease skin impedance, which reveals moisturizing property of Sericin. Sericin gels with pluronic and carbopol, act as moisturize $r$ by repairing natural moisturizing factor $(\mathrm{NMF})$ as well as helps in water loss from the skin. SEM has shown the decrease cracking and flaking as compare to dry skin and normal skin replicas.

Powder containing 5-30\% Sericin with average molecular weight 7,000-3,00,000 and 70-95\% silk fibroin when applied as film shows antistaticity and moisture absorbability (Kirikawa M, et.al., Silk protein micropowders for coating with excellent feeling, antistaticity and moisture absorbability and releasability and there manufacture, 2000). Sericin hydrolysate solution shows that dermatitis is controlled ( Yasuda N, et.al., Sericin from silk as dermatitis inhibitor 1998) Sweat and sebum absorbing type of cosmetics containing cellulose fibres impregnated with fibroin dispersion and aqueous Sericin solution are also reported (Miyashita T, Sweat and sebum absorbing cosmetics containing cellulose fibres, 1999). Lotion containing $1 \% \mathrm{w} / \mathrm{w}$ Sericin and $4 \% \mathrm{w} / \mathrm{w}$ $\mathrm{D}$-glucose shows moisturizing and conditioning effect (Yamada H, Yamazuki K \& Nozaki K, Skin moisturizing and conditioning cosmetics containing Sericin and saccharides, 2001) Creams containing $0.00130 \% \mathrm{w} / \mathrm{w}$ of Sericin have improved cleansing properties with less skin irritation (Sakamoto K \& Yamakishi K, Sericin containing cleaning composition, 2000). Sericin powder in the form of Sericin hydrolysate coated talc, mica; titania,

iron oxide, and nylon have been used to formulate foundation cream and eyeliners
(Yamada H \& Yuri O, Sericin coated powders for cosmetics, 1998). The microcapsules or nanocapsules consisting of polysiloxane gel, UV absorbant core and UV scattering age nt, silicone treated mica, silicon treated titanium dioxide, silicon treated iron oxides, squalene, glycerin trioctanoate, and talc have resulted in cosmetic foundation. Sericin in sunscreen composition enhances the light screening effect of UV filter like triazines, and cinnamic acids ester (Yoshioka M, et.al, UV absorbing compositions containing fine capsules, 2001).

Nail cosmetics, containing $0.0220 \%$ Sericin are reported to prevent nail from chapping, brittleness, and imparting the inherent gross to nails (Yamada $\mathrm{H}$, Yamasaki K \& Zozaki K, Nail cosmetics containing Sericin, 2001). Hair and bath preparations, containing $0.022 \%$ Sericin and $0.011 \%$ olive oil, fatty acid or their salts show reducing damage of hair surface by binding of Sericin to hairs (Hoppe U, Koerbaecher K \& Roeckl M, Hair and bath preparations containing Sericin,1984). Sericin hydrolysates are used as conditioners for skin and hair (Hata $\mathrm{O}$, Cosmetics containing Sericin hydrolysates, 1987). Shampoo containing Sericin and pelarogenic acid of $\mathrm{pH}$ less than six are useful for the care and cleaning of hairs.

\section{Conclusion:}

The silk protein sericin is currently mostly a waste mate rial of silk processing. But extensive research proves that sericin can be used in many medical, pharmaceutical researches and also its application in cosmetics such as wound healing, bioadhesive moisturizing, antiwrinkle and antiaging.

\section{References:}

Iizuka E, Silk (physicochemical properties), the polymeric materials encyclope dia (CRC Press) 1996.

Cook J G, Natural fibres of animal origin (Silk); Handbook of textile fibres (Marrow publishing Co Ltd, England), 3rd ed, 1964, pp 154-165.

Sprange $\mathbf{K} \mathbf{U}$, The Bombyx mori silk proteins: characterization of large polypeptides, Biochemistry, 14(5) (1975) 925-931.

Wang $\mathbf{T}$, Wang $\mathbf{J} \&$ Zhou $\mathbf{J}$, $\boldsymbol{\gamma}$ Ray study on the Sericin structure of cocoon silk, Fangzhi Xuebao, 6(3) (1985) 133-134.

Tsukada M, J Polym Sci: Polym Lett Ed, 18 (1980) 133-134.

Ayub Z H, Arai M \& Hirabayashi K, Biosci Biotechnol Biochem, 57 (11) (1993) 1910-1912.

Zhu L J, Yao J \& Youlu L, Structural transformation of Sericin dissolved from cocoon layer in hot water, Zhejiang Nongye Daxue Xue bao, 24(3) (1998) 268-272. Tsubouchi K, Yamada H \& Yoko T, Manufacture of high molecular weight Sericin by extraction, Jpn Kokai Tokkyo Koho Jap 11092564 A2 (to Norin Suisansho Sanshi Konchu Nogyo Gijutsu Kenkyusho, Japan) 06 
April 1999, He isei, pp 6; Chem Abstr, 130(22) (1999) 301746.

Padamwar M N \& Pawar A P, Preparation and evaluation of Sericin gels containing choline salicylate, Indian Drugs, 40(9) (2003) 526-531.

Hirabayashi K, Arai M \& Zhu L J, Gelation of silk Se ricin (Tokyo Agric Technol Univ, Tokyo 184, Jpan) Nippon sanshigaku, Zasshi, 58(1) (1989) 81-82.

Zhu, L J, Hizahayashi $\mathbf{K}$ \& Aari M, Gelation of Se ricin and its structure and properties, Canye Kexue, 17(1) (1991) 33-38.

Kewon H Y, Yeo J H, Lee K G, Lee Y W, Park Y H, Nahm J H \& Cho C S, Effect of poloxamer on the gelation of silk Sericin, Macromol Rapid Commun, 21 (2000) 1302-1305.

Nakamura $\mathbf{K}$ \& Koga $\mathbf{Y}$, Sericin containing polymer hydrogels and their manufacturer, Jpn Kokai Tokkyo Koho Jap 2001106794 A2 (to Mochida Shoko K K Japan) 17 April 2001, P 5; Chem Abstr, 134(21) (2001) 296862.

Yasushi T, Antithrombotic agent and its production me thod, Jpn Kokai Tokkyo Koho JAP 09227402 A2 (to Norin Suisansho Sanshi Konchu, Nagyo Gijitsu Kenkyusho, Japan) 2 September 1997, Heisei, pp 5; Chem Abstr, 127(16) (1997) 225-274.

Khudaiberdiev $\mathbf{M}$ A, Synthesis of copolymer processing an anticoagulant action, Chem Nat Compd, 33(5) (1997) 603--604.

Wu C, Tian B, Zhu D, Yan X, Cheng W, Xu G, Guo $\mathbf{Y}$, Wu Y \& Jia $\mathbf{S}$, Wound protection film and its preparation method, Faming Zhuanli Shenqing Gongkai Shuomingshu CN 1121836 (to Suzhou Silk Engineering College, China), 8 May 1996, pp 7; Chem Abstr, 130 (1996) 100662.

Gapurova G N, Chemical and physicochemical properties of surgical sutures, (Turk Gos Med Inst, Ashkhzbad, USSR), Zdravookhr Turkm, 27(7) (1983) 15-17.

Tsubouchi K, Wound covering material containing silk fibroin and silk Sericin as the main components and process for producing the same, PCT Int Appl WO 9857676 A1 (to National Institute of Sericulture, Japan) 23 December, 1998, pp 34; Che m Abstr, 130(4) (1999) 43418

Kurioka A, Application of silk proteins to new biomaterial (Silk Sci Res Inst Tokyo, Japan), Zairyo Gijutsu, 16(5) (1998) 195201

Sasaki M, Yamada $\mathbf{H}$ \& Kato $\mathbf{N}$, Composition of silk protein, Sericin elevates intestinal absorption of $\mathrm{Zn}$, $\mathrm{Fe}, \mathrm{Mg}$, and $\mathrm{Ca}$ in rats, Nutr Res, 20(10) (2000) 15051511 .

Sasaki M, Yamada $\mathbf{H}$ \& Kato $\mathbf{N}$, A resistant protein Sericin improves atropine induced constipation in rats, Food Sci Tech Res, 6(4) (2000) 280-283.

Sasaki M, Kato N, Watanabe $\mathbf{H}$ \& Yamada $H$, Silk protein Sericin suppresses colon carcinogenesis, Oncol Re p, 7(5) (2000) 10491052

Kato N \& Sasaki M, New physiological function of Sericin and its application for cosmetic and food, Fragrance J, 28(4) (2000) 2833.

Kato N, Tomotake $\mathbf{H}$ \& Sasaki M, Nutritional function of resistant protein (Fac Appl Biol Sci, Hiroshima Univ, Japan), Rinsho Eiyo, 97(7) (2000) 789-796.

Minora N \& Tsukada M, Oxygen permeable me mbranes, Jpn Kokai Tokkyo Koho Jap 02233128 A2 (to Agency of Ind Aci \& Tech, Japan; Ministry of agriculture \& forstry sericulture, Japan) 14 Septe mbe $r$ 1990, He isei, P 3; Chem Abstr, 114(6) (1991) 45871.

Yamada H, Fuha Y, Yuri O, Obayashi M \& Arashima T, Collagen formation promoters containing Sericin or its hydrolyzates and antiaging cosmetics, Jpn Kokai
Tokkyo Koho, JP 10226653 A2 (to Noevirco Ltd, Seiran co Ltd, Japan) 25 August 1998, Heisei, P 8; Chem Abstr, 129(14) (1998) 179985.

Yu-Qing Zhang, Applications of natural silk prote in sericin in biomaterials * Biotechnology Lab for Silkworm and Silk, Soochow University. Biotechnology Advances 20 (2002) $91-100$.

Ogawa, A \& Yamada H, Antiaging cos metic containing Sericin or hydrolysates and saccharomyces extracts, Jpn Kokai Tokkyo Koho Jap 11193210 A2 (to Noevier Co Ltd, Seiren Co Ltd Japan) 21 July 1999, Heisei, P 9; Chem Abstr, 131(7) (1999) 923508.

Henne W \& Hoppe U, Light and screening composition, Ger Offen DE 3408406 A1 (to Beiersdrof A G Fed Rep Ger) 12 September 1985, P 14; Chem Abstr, 104(6) (1986) 39519.

Padamwar M N, Daithankar A V, Pisal S S \& Pawar A P, Evaluation of moisturizing efficiency of silk protein II: silk Sericin, presented in sixty second World Cong of FIP, Nice (France) (31st August5th Se ptember 2002).

Padamwar M N, Pawar A P Erandwane, Silk Sericin and its applications: A review Journal of Scientific \& Industrial Research Vol. 63, April 2004, pp. 323-329.

Kirikawa M, Kasaharu T, Kishida $K$ \& Akiya ma D, Silk protein micropowders for coating with excellent feeling, antistaticity and moisture absorbability and releasability and there manufacture, Jpn Kokai Tokkyo Koho Jap 2000044598 A2 (to Daiwa Spinning Co Ltd, Nippon Ind Ltd, Japan) 15 February 2000, P 8; Chem Abstr, 132 (2000) 153-320.

Yasuda N, Yamada $\mathbf{H}$ \& Nomura $\mathbf{M}$, Se ricin from silk as dermatitis inhibitor Jpn Kokai Tokkyo Koho Jap 10245345 A2 (to Se iran Co Ltd, Japan) 14 Se ptember 1998, Heisei, P 4; Chem Abst, 129(16) (1998) 207197.

Miyashita T, Sweat and sebum absorbing cosmetics containing cellulose fibres, Jpn Kokai Tokkyo Koho, Jap 11152206 A2 (to Hsan Sangyo K K Japan) 8 June 1999, Heisei, P 3; Chem Abstr, 131(2) (1999) 23271

Yamada $H$, Yamazuki $K$ \& Nozaki $K$, Skin moisturizing and conditioning cosmetics containing Sericin and saccharides, Jpn Kokai Tokkyo Koho Jap 2001064148 A2 (to Seiren Co Ltd \& Teikoku Seiyaku Co Ltd) 13 March 2001, P 6; Chem Abstr, 134(16) (2001) 227100

Sakamoto $\mathbf{K}$ \& Yamakishi $\mathbf{K}$, Se ricin containing cleaning composition, Jpn Kokai Tokkyo Koho Jap 2000073090 A2 (to Se iren Co Ltd, Japan) 7 March 2000, P 4; Chem Abstr, 132 (2000) 196164.

Yamada H \& Yuri O, Sericin coated powders for cosmetics, Jpn Kokai Tokkyo Koho Jap 10226626 A2 (to Noevir Co Ltd, Seiren Co Ltd, Japan) 25 August 1998, Heisei, P 9; Chem Abstr, 129(16) (1998) 207009. Yoshioka M, Segawa A, Veda A \& Omi S, UV absorbing compositions containing fine capsules, Jpn Kokai Tokkyo Koho Jap2001049233 A2 (to Seiwa Kasei K K Japan) 20 February 2001, P 14; Chem Abstr, 134(14) 197870.

Yamada H, Yamasaki $\mathbf{K}$ \& Zozaki $\mathbf{K}$, Nail cosmetics containing Se ricin, PCT Int Appl WO 2001015660 A1 (to Teikoku Seiyaku Co Ltd Seiren Co Ltd Japan) 8 March 2001, P 15; Chem Abstr, 134(14) (2001) 197888

Hoppe U, Koerbaecher $\mathbf{K} \&$ Roeckl $\mathbf{M}$, Hair and bath preparations containing Sericin, Ger Offen DE 3233388 A1(to Beiersdorf A G, Ger) 15 March 1984, P 15; Che m Abstr, 100 (1984) 215-305. 